\title{
COMPUTER SIMULATION - EFFICIENT TOOL OF CRISIS MANAGEMENT
}

\author{
Rudolf URBAN, Alena OULEHLOVÁ, Hana MALACHOVÁ \\ University of Defence, Brno, The Czech Republic \\ rudolf.urban@unob.cz, alena.oulehlova@unob.cz, hana.malachova@unob.cz
}

\begin{abstract}
The paper presents an analytical evaluation of the advantages of computer simulation of emergency situations within crisis management processes optimization. It affirms the efficiency of the preparation of crisis staffs, their coordination, communication and cooperation on the practical example of the SIMEX simulation tool.
\end{abstract}

\section{Keywords: crisis management, communication, exercise, simulation}

\section{Introduction}

Computer simulations have recently become a useful tool. They include modelling of natural or human systems to gain insight into their functioning. Another context includes technology simulations for optimizing the performance, safety engineering, testing, training and education. Simulation tries to imitate the reality or its alternative forms as well as subsequent impacts of its actual implementation [1]. Therefore, defining variables of the given model belongs among the key issues in simulation. Parameters taken from the real environment, selection of the key characteristics and behaviour together with the use of simplified scheme of simulation help to approximate the credibility of the simulation results [2].

Simulation is often used in training and in the cases when it is too expensive or too dangerous for the participants to use real devices or created situation in the real world [3]. In these cases, instruction and training to acquire the necessary experience takes place in a "safe" virtual environment. Computer simulations have additional benefit compared to training in particular reality that they allow participants to make mistakes without consequences when taking their decision. Approach to learning through an interactive process involving the possibilities of re-evaluation of the decisions taken and their subsequent recorrection is then far more effective.

Programmed emergency situations and accidents are used for comprehensive training [4]. Their added value lies in an infinite number of reproducibility without increasing costs. Fully functional 3D simulator should be the most accurate tool for acquiring the necessary knowledge as well as skills of the trainees.

\section{Training of crisis staffs at the regional and municipality levels}

Based on the evaluation of the exercises of crisis staffs carried out at the level of regions and municipalities, demand for the creation of a virtual training environment has arisen. Practical experience has indicated the structure of the virtual training environment which would create conditions for crisis staffs preparation. This form of training of all participants supports the efficiency in 
managing real crisis situations. Among the analytical findings resulting from performed exercise together with requirements of supervisors and implementers of the exercise, the following needs have emerged: (a) to improve the quality of training of the personnel by approximating the simulation as much as possible to the actual conditions of a crisis situation which a classic staff exercise cannot fully allow, (b) to create conditions for the training in the critical situations without endangering persons and property within acceptable economic aspects which will take into account also ecological issues of saving fuel and considerate approach to nature, (c) to create conditions for dynamic spatial and temporal course of exercise with the possibility to repeat imperfectly mastered activities and within the complexity of preparing to give space for alternative procedures in dealing with emergency situations, (d) to ensure the objectivity of verification of the performance of participants using recordings of decision-making processes, communication and responses of the trainees to simulated actions.

\section{Simulation and its application}

Department of Emergency Management of the University of Defence participates in the development of SIMEX simulation system within a scientific research project. The simulator creates conditions for preparation of crisis staffs where the trainees practice complex cooperation between the elements of crisis management self-government, emergency services and critical infrastructure elements. This form of training of all participants supports efficiency in managing real crisis situations.

In a real emergency situation, participants do not have enough time and therefore they must be prepared to act according to rehearsed standards. Simulation exercises in a virtual environment provide an opportunity to capture as much information as possible and practice its knowledge in a safe environment. In this way, they can make mistakes without risk of endangering lives and participants can get an opportunity to correct their errors and thus be prepared for a real emergency situation.

\subsection{Possibilities of the simulator}

SIMEX simulation system not only allows a complex simulation of events, but also allows to simulate only a certain period of time, which can speed up or slow down time for the course of the trained situation according to the need for development of the skills of participants. The system can record the progress, has navigation through image display, storage of data from individual simulations and launch of external applications. The basis forms a gaming environment which allows the user to fix sills through visual perception. Training efficiency is increased by the fact that the environment is tailored to the needs and so can be a real copy of the reality which for example fully respects altitude profiles as well as objects distribution in the scenery.

Simulator carries out simulation of processes, activities, actions and phenomena within the model of the geographical area corresponding to the area of interest. For the needs of simulation, terrain must meet certain requirements for the data organization and characteristics of this data. All the data necessary for the description is stored in so-called terrain database as a result of the requirement for their optimal processing by the simulator.

A key element of the simulator and the training itself of its participants is the security of information transmission among participants. The simulator allows communication between trainees to be provided by a closed circuit with various types of alternative terminal communication equipment. Communication of information is recorded simultaneously with the course 
of simulation. Interconnection and end elements are configurable. Among the terminal equipment in the process of communication belong simulated [5]:

- telephones for voice transmission;

- radios for voice transmission;

- terminals for sending short text messages;

- terminals for sending e-mails;

- terminals for the transmission of images, documents etc.

According to the variety of communication protocols and requirement for synchronous recording, it is suitable from the technical point of view to make conversion of this data into a single type which will be further processed and stored.

\subsection{Communication architecture}

Standardized communication protocols were created for the simulation according to
The needs of training and integration of communication means resulting from it as a part of a training simulator (Figure 1).

Preparation of the exercise requires consistent communication with network administrators in different locations of the exercise and checking a proper connection.

Failed connection can seriously disrupt the exercise. Especially in the case of larger exercises it is not possible to continuously monitor all events and therefore training simulator equipment comprises means for supporting evaluation of the course of the exercise. These devices continuously monitor and store events and activities in the simulation, communication and other activities of the exercising participants and the resulting record is then ready for use during the analysis and evaluation of the achieved results of the simulation.

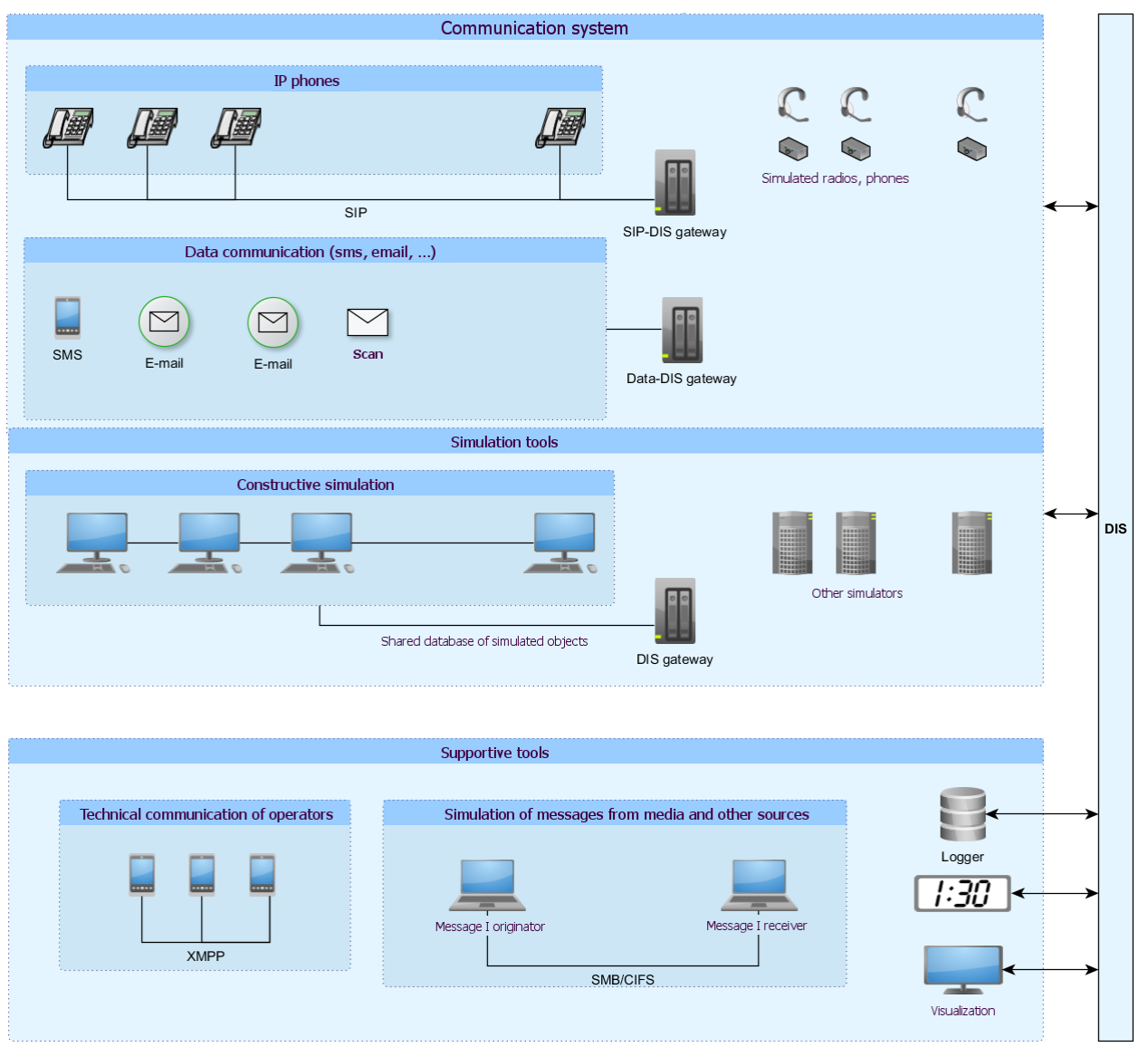

Figure 1: Scheme of a possible structure of the SIMEX training environment [6] 
Communication architecture of the SIMEX simulator is flexible and multilevel as can be seen in Figure 1. Basic architecture of the simulation system is built as a "clientserver". Between the end elements of the simulation system is a plurality of layers (Figure 2) allowing division of a complex system into smaller parts which can be better tested and possibly even replaced etc.

\subsection{Simulator communication}

Simulator is designed on the „client-server” architecture basis. A relatively low-level access was used which is very flexible but ensures shielding of the communication level of the operation system from processing data by the simulator. At the same time, communication protocols containing mechanism which ensures safe delivery of the massage (TCP) or its effective distribution among more nodes (PGM) is used.

Object database containing actual status of the simulation is built over this communication level which ensures synchronisation of the objects among the nodes in the simulation. Simulation models themselves work with the objects contained in this database. Based on the simulation, modification of the parameters of the objects and subsequent distribution of changes among the clients of the simulation by the means of the operating server takes place. Figure 2 shows transfer of data among the individual nodes of the simulator.

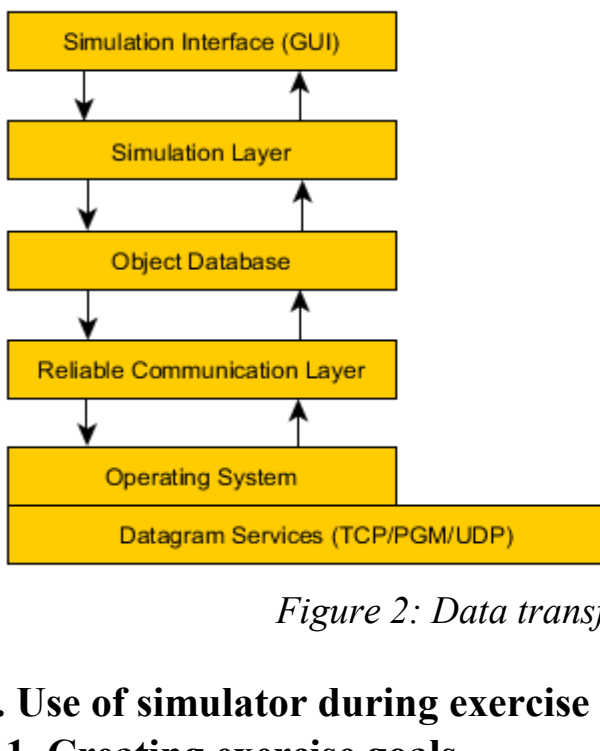

\subsection{Creating exercise goals}

To illustrate the usefulness of the SIMEX simulator, process of creating the goals of the exercise and expected skills has been presented.

Goals of the exercise determine what the exercise organizing body wants to achieve during the exercise. The exercise goals should include officials objective, plans and procedures of the trainees, environment in which the exercise takes place and desired results. Generally, people who plan the exercise should choose a reasonable number of specific, measurable, achievable, relevant and time-limited (SMART) exercise goals to facilitate the draft of the scenario, its implementation and evaluation. Table 1 shows the description of SMART goals. 


\begin{tabular}{|l|l|}
\hline Specific & $\begin{array}{l}\text { Goals should meet the } 5 \mathrm{~W}-\text { who, what, when, where and why. The } \\
\text { goal specifies what has to be done at a certain time for its } \\
\text { completion. }\end{array}$ \\
\hline Measurable & $\begin{array}{l}\text { Goals should contain numeric or descriptive measures which define } \\
\text { quantity, quality, costs, etc. It is necessary to focus on observable } \\
\text { actions and results. }\end{array}$ \\
\hline Achievable & $\begin{array}{l}\text { Goals should be verifiable and achievable with the resources and } \\
\text { participants. }\end{array}$ \\
\hline Relevant & $\begin{array}{l}\text { Goals should serve as a tool for the organization's mission and be } \\
\text { related to its objective and a strategic plan. }\end{array}$ \\
\hline Time-limited & $\begin{array}{l}\text { All goals should be specific and achievable within a limited } \\
\text { timeframe. }\end{array}$ \\
\hline
\end{tabular}

\subsection{Exercise goals}

In 2016 an exercise focused on the largescale interruption of gas supplies took place. The aim of the exercise was to examine the activities of the gas distributor, the Integrated Rescue System (IRS) and crisis management authorities in dealing with the gas pipeline accident and the direct consequences of a natural gas supply failure including dealing with the secondary impacts of this emergency situation. In addition to the main goal of the exercise, partial goals were set which should especially practice [8]:

- work of the IRS components during emergency situation emergence and coordination with the emergency service of the natural gas distributor;

- activity of the natural gas distributor declaring a state of emergency in the gas industry, supply restoration;

- communication flows between crisis management bodies, IRS components, natural gas distributor and other entities involved in dealing with emergency situation;

- convening and operation of the regional crisis staff, staff of regional fire rescue service and crisis staffs of affected municipalities with extended powers under the principles set out in the Guidelines of the Ministry of Interior and internal documentation of participants,

- operation of crisis management authorities during emergency situation and declaring a state of emergency;

- procedures for the coordination of crisis management authorities and natural gas distributor;

- informing the media and the population about the emergence and anticipated impacts of a large-scale natural gas supply failure;

- ensuring emergency survival of the population, the work of NGOs

- ensuring cooperation between operators of critical infrastructure, bodies fulfilling the regional crisis plan, schools and healthcare facilities, etc.

Another objective was to test [8]:

- meeting the requirements put on the training solution of the SIMEX simulator for crisis management authorities;

- procedures set out in the emergency plan of a natural gas distributor;

- IRS regional emergency plan, regional emergency and crisis plan and regional crisis plans of municipalities with extended powers in relation to the fulfilment of the set tasks, plans of crisis preparedness of critical infrastructure bodies and bodies 
dealing with tasks of the regional emergency plan;

- feasibility and timeliness of developing the type plan;

- communication standards

(communication between crisis staffs, IRS components and other concerned parties);

- notification of relevant crisis management authorities, local administrative authorities and the IRS components;

- procedures for the coordination of crisis management authorities in the process of addressing the requirements for material resources in order to effectively utilize the available material resources;

- PANEL of nongovernmental nonprofit organizations' activities in providing humanitarian help.

\section{Conclusions}

Developed SIMEX simulation tool is a userfriendly and flexible tool to simulate the reality and creating unique situations for training tactical actions of the crisis staffs and other stakeholders involved dealing with crisis situations. SIMEX simulator takes into account practical experience and increases the illustration of education and training. At the same time it allows to insert various elements of the scenario in the form of complicating elements of the dealt crisis situation." The final version of the simulator should be an efficient contribution to the preparation of crisis managers who will flexibly manage the decision making processes and communication standards during a crisis situation.

\section{Acknowledgements}

Results presented in this article were obtained as a part of the solution of the project by Technology Agency of the Czech Republic with the topic Research and Development of Simulation Instruments for Interoperability Training of Crisis Management Participants and Subjects of Critical Infrastructure (research project No. TA04021582).

\section{References}

[1] Pelanek, Radek. Modelování a simulace komplexních systémů: jak lépe porozumět světu. Brno: Masarykova univerzita, 2011. ISBN 978-80-210-5318-2.

[2] Rainey, Larry B. and Andreas. Tolk. Modeling and simulation support for system of systems engineering applications. ISBN 978-1-118-46031-3.

[3] Řezač, David. Výcvik součinnosti subjektů kritické infrastruktury a orgánů státní zprávy S využitím počítačové simulace [online]. 2015. Available at:http://fbiw.uniza.sk/rks/2015/articles/Rezac.pdf

[4] Niemeyer, Klaus. Simulation of Critical Infrastructures. Information. 2005, 17, pp. 120143. DOI: 10.11610/isij.1708. ISSN 08615160.

[5] Kolektiv autorů. Odborná zpráva o postupu prací a dosažených výsledcích za rok 2016. Výzkum a vývoj simulačních prostředků pro výcvik součinnosti aktérů krizového řízení a subjektů kritické infrastruktury. Průběžná zpráva za rok 2016. Brno: VR Group and University of Defence, 2016, p. 12.

[6] Kolektiv autorů. Simulační prostředek - Framework. Výzkum a vývoj simulačních prostředků pro výcvik součinnosti aktérů krizového řízení a subjektů kritické infrastruktury. Př́loha k průběžné zprávě 2016. Brno: VR Group and Universiy of Defence, 2016, p. 51.

[7] Homeland Security Exercise and Evaluation Program (HSEEP) [online]. Washington: Homeland Security, 2013. Available at: https://www.fema.gov/media-librarydata/20130726-1914-25045-8890/hseep_apr13_.pdf 
[8] Kolektiv autorů. Simulační prostředek - Příprava experimentálního cvičení. Výzkum a vývoj simulačních prostředků pro výcvik součinnosti aktérů krizového řízení a subjektů kritické infrastruktury. Příloha k průběžné zprávě 2016. Brno: VR Group and University of Defence, 2016, p. 46.

[9] Grega,M. Simulácie pre civilný krízový manažment a Computer Assisted eXercise,Liptovský Mikuláš, 2016. 